\title{
Climate Change and Soil Degradation Mitigation by Sustainable Management of Soils and Other Natural Resources
}

\author{
Rattan Lal
}

Received: 11 July 2012/ Accepted: 30 July 2012/Published online: 6 September 2012

(C) NAAS (National Academy of Agricultural Sciences) 2012

\begin{abstract}
Soil, an important component of land, has numerous functions and ecosystem services essential to all terrestrial life. Soil degradation, decline in its capacity to support functions and provide ecosystem services, is caused by accelerated erosion, salinization, elemental imbalance, acidification, depletion of soil organic carbon (SOC), reduction in soil biodiversity, and decline in soil structure and tilth. Desertification, a sub-set of degradation, specifically refers to decline in soil quality and functions in arid climates. Climate change affects and is affected by soil degradation through a positive feed back due to increase in mineralization of SOC pool and the radiative forcing. Desertification may lead to a net increase in temperature despite change in albedo of the denuded surface. Feedbacks and threshold amplify the risks of degradation, and the projected climate change may exacerbate all four types of drought (i.e., meteorological, hydrological, pedagogical, and ecological). The mutually reinforcing positive feedbacks between soil degradation and climate change are strongly influenced by social, economic, political, and cultural factors. There exists a strong link between poverty, desperateness, and societal collapse on soil degradation and climate change. Restoration of degraded and desertified soils, converting marginal agricultural areas to rangeland and forest land, and adoption of recommended management practices have a large technical potential to sequester carbon and off-set anthropogenic emissions, improve the environment, and enhance and sustain agronomic productivity. Important among recommended management practices are using conservation agriculture and mulch farming, establishing cover crops, adopting strategies of integrated nutrient management, and those which create positive $\mathrm{C}$ and nutrient budgets and soil/water conservation within a watershed. Long-term research is needed which is hypothesis-driven, uses modern innovative research and modeling tools, is based on community involvement, and provides decision support systems to policy makers and land managers.
\end{abstract}

Keywords Soil resilience - Degradation - Desertification - Climate change - Natural resources management . Soil restoration $\cdot$ Watershed management $\cdot$ Carbon sequestration

\begin{abstract}
Abbreviations
AWC: Available water capacity; C: Carbon; CBNRM: Community-based natural resource management; DSS: Decision support system; ESs: Ecosystem services; GHGs: Greenhouse gases; INM: Integrated nutrient management; LCA: Life cycle analyses; NRM: Natural resource management; NPP: Net primary productivity; NT: No-till; RMPs: Recommended management practices; SOC: Soil organic carbon; WANA: West Asia North Africa
\end{abstract}

\section{Introduction}

R. Lal ( $\square)$

Carbon Management and Sequestration Center,

School of Environment and Natural Resources,

The Ohio State University, Columbus, OH 43210, USA

e-mail: Lal.1@osu.edu
Land refers to the part of Earth's surface that is not covered by water, and is a topographically or functionally distinct tract. The land domain includes everything from top of the atmosphere to the bedrock and beneath (in Latin = Cuius est solum eius est usque et ad inferos). Thus, land consists 
of atmosphere, vegetation, water, terrain, and all biota above the surface and ground water and minerals below the surface. Soil is an important component of land. Soil is a four dimensional body (length, width, depth, and time), at the interface between atmosphere and the lithosphere, and essential to all terrestrial life. Functionally, soil is also geomembrane of the earth, protective filter, buffer, and mediator of energy, water and biogeochemical compounds, reservoir of a very large germpool, and archive of planetary history.

Soil degradation implies decline in its capacity to provide ecosystem services (ESs) of interest to humans and useful to nature's functions. Principal processes of soil degradation are erosion, salinization, nutrient and carbon (C) depletion, drought, decline in soil structure, and tilth. Examples of ESs provided by soil include ecological/supporting (biomass production, nutrient cycling), regulating (water purification and flow, $\mathrm{C}$ sequestration, temperature fluctuations), provisional (food, fiber, fuel, and forages), and cultural (aesthetical, spiritual, and cultural). Erosioninduced degradation diminishes soil's capacity to provide ESs, and support ecosystem functions.

Desertification refers to land degradation in dry/arid regions, which cover approximately $41 \%$ of the continental area [92]. It is the diminution or destruction of the biological potential of land, and can lead ultimately to desert-like conditions [97]. Thus, desertification is a sub-set of land degradation and specifically refers to decline in quality and functionality of soil, vegetation, water, biota, and climate in dry regions. Soil erosion is one of the processes of desertification. Others include salinization, depletion of plant nutrients and soil organic carbon (SOC) pool, reduction in plant available water capacity (AWC) and the overall decline in net primary production (NPP), and denudation of the vegetation cover.

Soil erosion implies physical removal of the soil by tillage, wind, gravity, raindrop splash, surface run-off, stream flow, coastal processes, and chemical dissolution. In the more common forms of water (inter-rill and rill) and wind erosion, the processes comprise of four distinct but inter-related phases: detachment, transport, redistribution, and deposition. The impacts of erosion on soil quality, and ecosystem functions and services depend on the rate $(\mathrm{Mg} /$ ha/year, mm/year) of soil erosion vis-a-vis the rate of soil renewal ( $\mathrm{mm} /$ century or millennia). The accelerated soil erosion, when the rate of soil removal exceeds that of its renewal, has adverse on- and off-site effects. The on-site adverse effects of severe erosion are due to loss of the effective rooting depth, reduction in plant-AWC, depletion of SOC and plant nutrients, decline in soil structure, and reduction in soil quality. The off-site effects of erosion are caused by run-on and inundation, sedimentation, non-point source pollution, and emission of greenhouse gases
(GHGs) into the atmosphere. The agronomic, economic, and environmental effects of accelerated erosion are colossal at regional and global scales.

The objective of this review is to describe processes, causes, and factors of soil degradation by erosion and desertification; describe the importance of climate change on these processes; and outline principles and practices of sustainable management of soil and other natural resources.

\section{Climate Change and World Soils}

The Green Revolution and other technologies since mid twentieth century were developed under an assumption of a stable climate. However, current and protected climate change poses severe challenges. Thus, it is pertinent to understand the followings [101]: (i) climate impacts to soil and ecosystem processes, (ii) relation between land use/ management and soil/ecosystem resilience, (iii) opportunities for successful implementation of adaptation and mitigation strategies, and (iv) the process of feasible decision making with consideration of scale and thresholds. The terrestrial biosphere and soils have been the source of GHGs, (i.e., $\mathrm{CO}_{2}, \mathrm{CH}_{4}$, and $\mathrm{N}_{2} \mathrm{O}$ ) for thousands of years as a result of agriculture and the attendant deforestation, biomass burning, soil tillage, cultivation of paddy rice (Oryza sativa), and domestication of livestock. Ruddiman $[79,80]$ argued that cyclic variations in $\mathrm{CO}_{2}$ and $\mathrm{CH}_{4}$ caused by Earth's orbital changes caused decreases in atmospheric concentrations of these GHGs throughout the Holocene. However, increase in atmospheric concentration of $\mathrm{CO}_{2}$ around 8,000 years ago and that of $\mathrm{CH}_{4}$ around 5,000 years ago corresponded with the onset of early agriculture in Eurasia and of rice cultivation in Asia, respectively. This hypothesis is supported by the argument that despite the low population density, early per capita land use was large because of extensive or extractive farming [81]. It is also argued that warming caused by these early gaseous emissions, estimated at $320 \mathrm{Pg} \mathrm{C}$ during the pre-industrial era compared with $160 \mathrm{Pg} \mathrm{C}$ since 1750 , reached a global mean value of $0.8{ }^{\circ} \mathrm{C}$ [79]. Soils of most agro-ecosystems may have lost $30-50 \%$ of the antecedent SOC pool in temperate regions and $50-75 \%$ in the tropics $[41,42]$. Total emissions from world soils have been estimated at 60-80 Pg C [39]. The magnitude of SOC depletion is exacerbated in soils prone to degradation by accelerated erosion, decline in structure, depletion of nutrients, and reduction in plant-AWC. Indeed, there exists a strong link between desertification, accelerated erosion, and climate change. There are several important aspects of the climate change in the context of drylands. These are: (i) decrease in annual rainfall amount, (ii) change in duration of rainfall events, (iii) increase in interval between the 
rainfall events, (iv) increase in temperature-induced evaporation, (v) increase in water run-off, and (vi) decrease in soil water storage. Increase in frequency of extreme events has been already reported in Africa [91]. Whereas the equilibrium water infiltration rate may be the dominant process affecting water storage in the Mediterranean type climate, overland flow (surface run-off) is often the control variable in arid regions [49]. Thus, climate-induced effects on water resources and availability to plants are highly complex. However, increase in temperature and decrease in effective rainfall provide a strong positive feedback which accentuates the rate of SOC decomposition and emission of $\mathrm{CO}_{2}$ into the atmosphere (Fig. 1). Field work conducted along a climatic transect from the Mediterranean climate to the arid zone in Israel showed that SOC concentration and aggregate size and stability decreased with increase in aridity, and the rate of change of these variables along the climate transect was nonlinear [49]. Global average increase in surface temperatures since the beginning of the twentieth century, corresponding with decrease in the frequency of air frosts over mid-latitude northern continents [83] may be due to emissions of GHGs from fossil fuel combustion and land use conversions [34]. The land-use conversion has been an important factor in the total anthropogenic emissions with an attendant increase in radiative forcing. The gap between agronomic production and food demand, already affecting more than one billion people, is likely to increase by the projected climate change, especially so in marginal areas such as in the Arab countries [28].

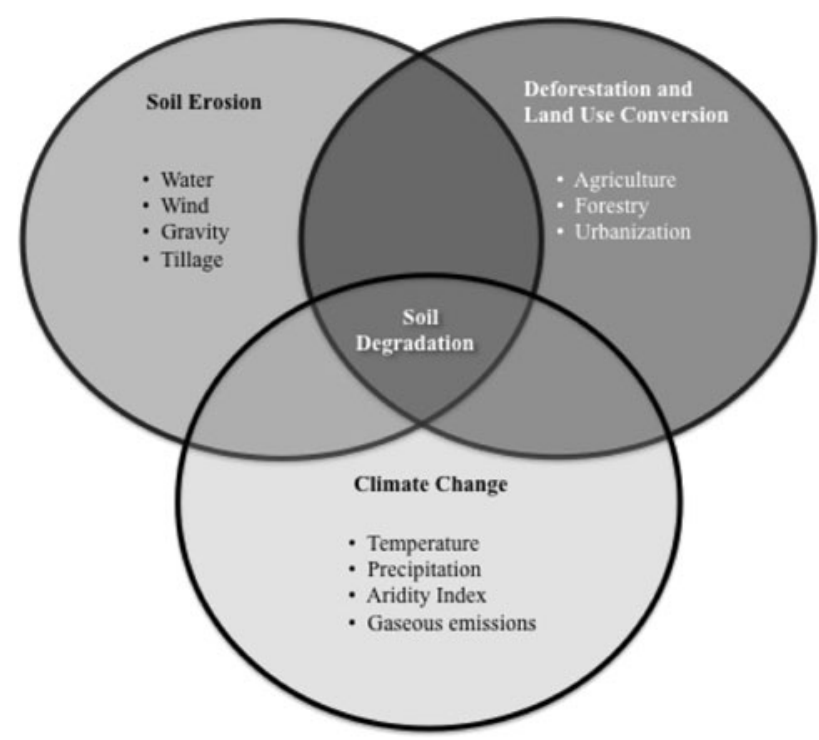

Fig. 1 A strong interaction of desertification and drought with accelerated soil erosion, deforestation/land-use conversion, and climate change

\section{Climate Change and Soil Degradation and Desertification}

Desertification is defined as the irreversible extension of desert landforms and landscapes to areas where they did not occur in a recent past [51]. Over and above any possible impacts of climate change, soil degradation, and desertification are also caused by long-lasting and perpetual mismanagement by extractive practices. Perpetual mismanagement can replace the climax vegetation in a specific biome because of soil degradation. It has been reported that changes in land-uses, fire regimes, and climate change are replacing the tropical humid forest by a savanna (grass) vegetation in the Amazon Basin [98]. As many as 100 countries are prone to desertification [32]. Estimates of global land area affected by land degradation (Table 1) and desertification $[21,64,96]$ vary widely because of the lack of credible data based on ground truthing, and thus reliance on proxy methods. Therefore, there is a strong need of strengthening the scientific basis for dryland ecosystems [77]. Similarly, there also exist major challenges in establishing the direct cause-effect relationship between climate change and desertification/erosion. Increase in the land use under hyperarid $(+50.7$ Mha or $1.5 \%)$ and arid $(+3.1$ Mha or $0.1 \%$ ) regions between 1931-1960 and 1961-1990 has been linked to climate change [32]. Despite the widespread belief in strong interaction between climate and desertification [90], it is difficult to state that climate change has caused desertification because of major uncertainties in obtaining credible site-specific data for both independent (climate change) and dependent (desertification, erosion) parameters [40] at the desired temporal and spatial scales. On the contrary, some have hypothesized that desertification (independent variable) may have increased the temperature (dependent variable) of the desertified lands [8]. It is also believed that dryland ecosystems are more resilient to climate variability than hitherto presumed [71] probably because of the combination of an opportunistic response of some of its species and prevalence of a wide range of buffering mechanisms. Important among the buffering mechanisms are spatial mosaics of vegetated and bare patches enhancing hydrological links among two [70]. Sediment

Table 1 Estimates of land area affected by land degradation (Modified and adapted from Bai et al. [6])

\begin{tabular}{ll}
\hline Parameter & Value \\
\hline Area affected $\left(10^{6} \mathrm{~km}^{2}\right)$ & 35.06 \\
Percent of the land area & 23.54 \\
Total NPP Loss $(\mathrm{Tg} \mathrm{C} / \mathrm{y})$ & 955 \\
Percent of total population affected & 23.9 \\
Total population affected (billion) & 1.54 \\
\hline
\end{tabular}


trapment by vegetated patches enhances redistribution of water and nutrients. Thus, banded vegetation patterns (called "tiger bush" in the Sahel) may be an adaptation to harvest the run-off [69]. Yet, case studies on dryland degradation in relation to climate change show that some transition-triggered events are caused by combination of anthropogenic and climate factors. In drought-prone environment, there is a close link between desertification and erosion (Fig. 2) and desertification is accentuated by over exploitation to beyond its resilience thresholds. Yet, the problem of data credibility cannot be completely ignored in this analysis. The challenge of establishing the cause-effect relationship is also aggravated because of the confounding effects of soil degradation and climate change on the water resources, and on net primary productivity (NPP). Feddema [25] hypothesized that, on a continental scale, the impact of global warming on African water resources may be greater than that of soil degradation. A possible increase of $1-3{ }^{\circ} \mathrm{C}$ in arid lands corresponding with atmospheric $\mathrm{CO}_{2}$ abundance of 700 ppmv would increase potential evapotranspiration by $75-225 \mathrm{~mm} /$ year [52], and drastically reduce NPP. For example, Oba et al. [62] reported that both NPP and desertification in Sub-Saharan Africa may be influenced by the global climate variability, with positive feedback on desertification, climate change, and water resources.
Climate change also impacts two among principal processes of desertification-erosion and salinization. Soil erosion hazard depends on climatic erosivity, soil erodibility, and land and crop management practices (Fig. 3). Climate change can impact all of these parameters and greatly accentuate the erosion hazard. Increase in frequency and intensity of extreme events would enhance rainfall intensity and its kinetic energy, wind velocity and its erosivity, and run-off velocity and its shearing and sediment carrying capacity. Furthermore, erosivity of wind-driven rain and that of shallow overland flow impacted by raindrops is more than that of a rain without wind and of a laminar overland flow. Soil erodibility increases with decrease in aggregation and reduction in aggregate strength caused by increase in slaking due to reduction in SOC concentration. Progressive desertification of the dryland tropics may reduce already low amount of SOC stored in these soils [32]. Furthermore, desertification may also alter the emission of GHGs from these ecologically sensitive and fragile ecosystems. Thus, warminginduced decline in SOC pool and aggregation [49], combined with increase in land conversion to meet the growing human demands, may severely accelerate soil erosion and desertification hazard. Wind erosion hazard, one of the major degradation processes in drylands [92] may also be

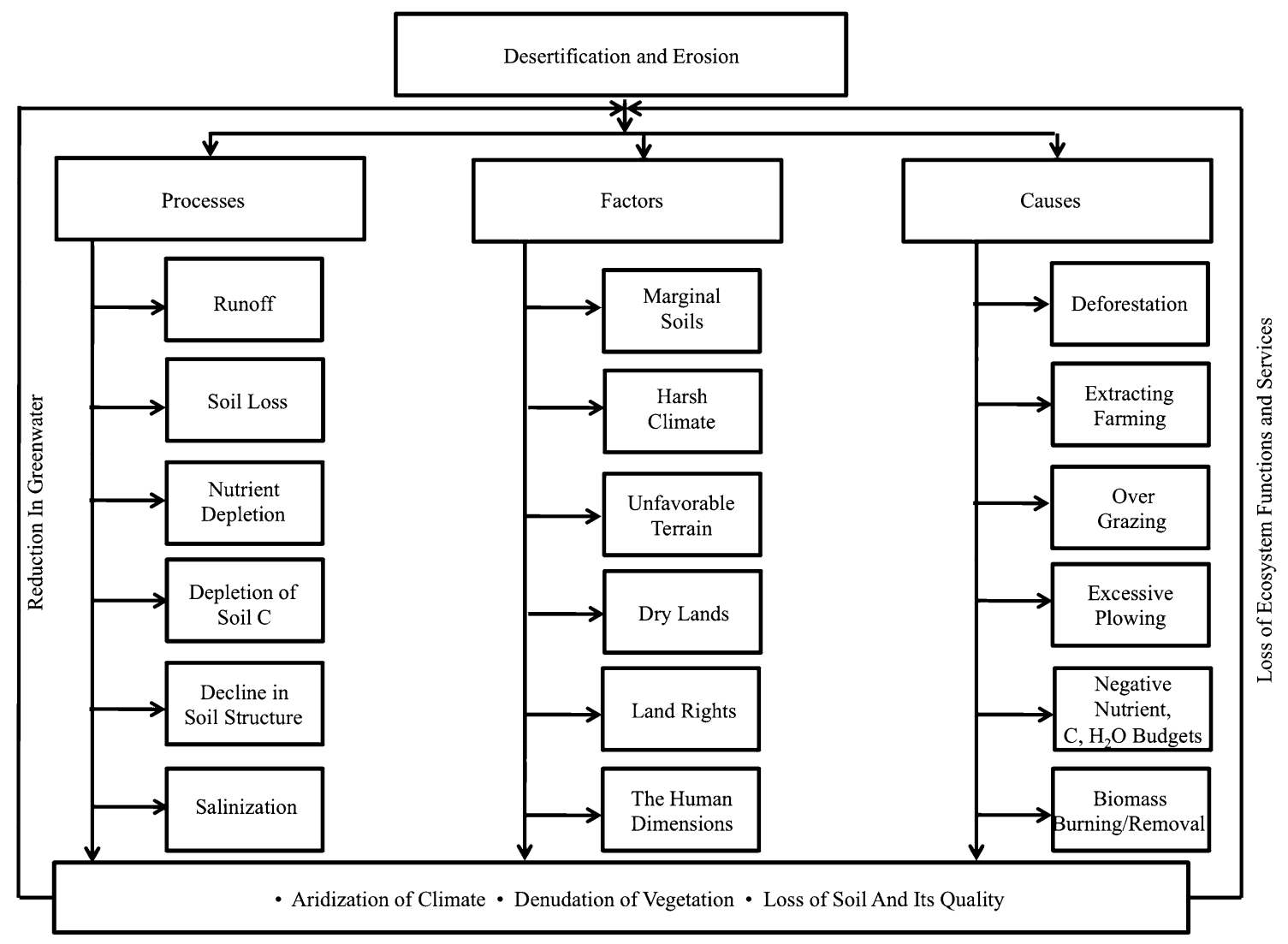

Fig. 2 Processes, factors, and causes of desertification and erosion 


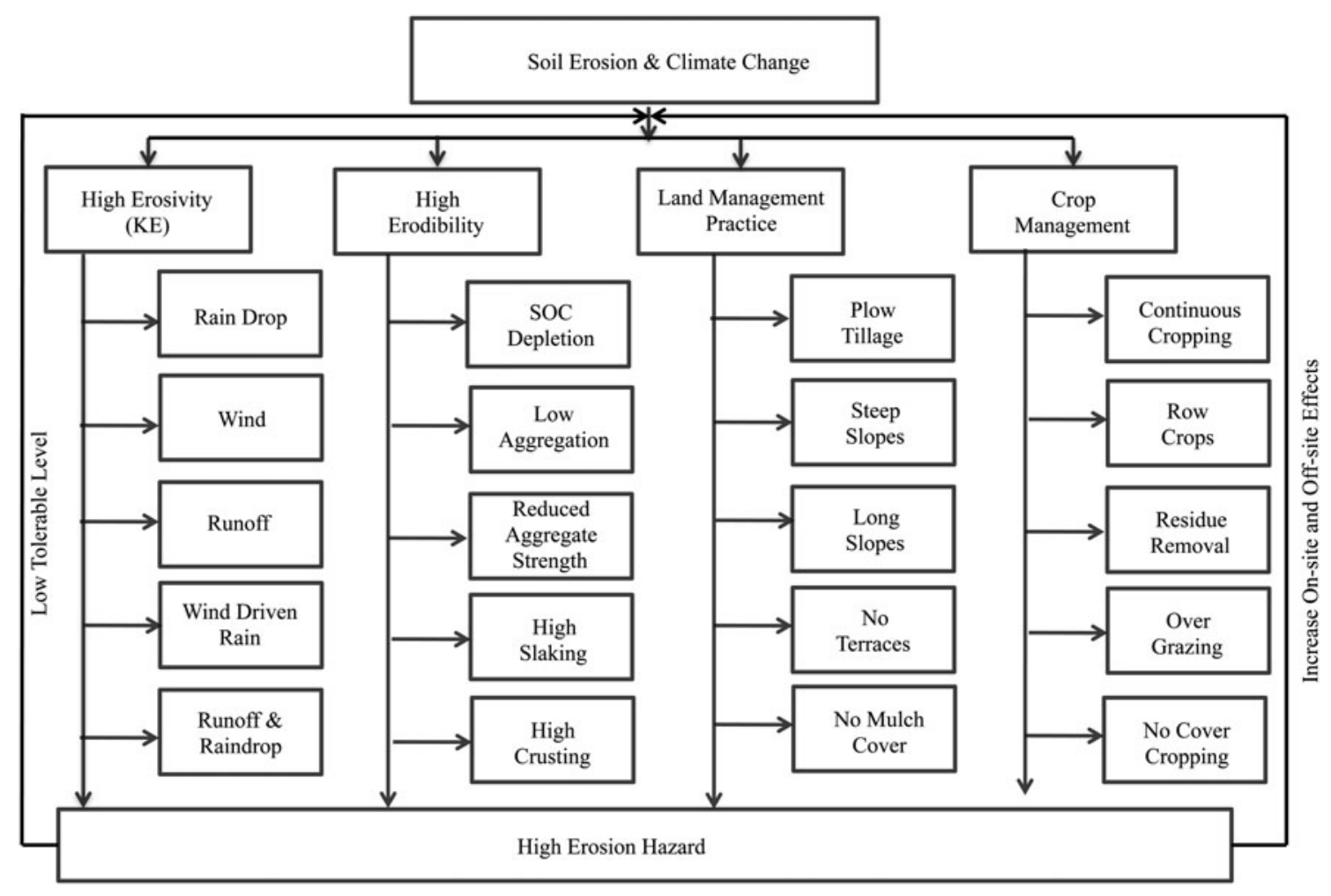

Fig. 3 Increase in risk of soil erosion and desertification due to climate change

increased because of the protected climate change in arid regions [104]. In accord with the argument outlined in Fig. 3, the data in Table 2 shows that the mean rate of continental soil erosion $(\mathrm{Mg} / \mathrm{ha} / \mathrm{year})$ may increase between 1980 and 2090s in all continents except Europe. The global soil erosion hazard is projected to increase by $14 \%$ with the highest increase in Africa. Yang and co-workers hypothesized that the effects of climate change on accelerated erosion is larger than that of land use conversion, with $9 \%$ increase due to climate change and $5 \%$ to land-use conversion. The regions with increasing trends of population and climate change may experience severe risks of accelerated soil erosion. The global increase in erosion will be
$18.2 \times 10^{9} \mathrm{Mg} /$ year with $\sim 11.6 \times 10^{9} \mathrm{Mg}$ due to climate change (Table 2). The serious problem of soil salinization [75] may also be aggravated by the projected aridization caused by an increase in potential evapotranspiration.

The confounding effect of land use conversion on climate change and desertification/erosion because of feedback, thresholds, and non-linearity cannot be ignored. Feedbacks and threshold amplify the risks causing degradation to increase disproportionally faster than populationinduced land-use conversion [29]. Among several reasons of the disproportional increase are: (i) reduction in sink capacity of the degraded land to absorb pollutants including $\mathrm{CO}_{2}$, (ii) decrease in soil resilience because of decline
Table 2 Estimates of soil erosion at continental scale between 1980 and 2090 (recalculated from Oldeman [64] and Yang et al. [104])

\begin{tabular}{|c|c|c|c|c|c|}
\hline \multirow[t]{2}{*}{ Continent } & \multirow[t]{2}{*}{$\begin{array}{l}\text { Land area } \\
\left(10^{6} \mathrm{ha}\right)\end{array}$} & \multicolumn{2}{|c|}{$\begin{array}{l}\text { Potential soil erosion } \\
\text { rate }(\mathrm{Mg} / \mathrm{ha} / \text { year })\end{array}$} & \multicolumn{2}{|l|}{ Total increase } \\
\hline & & $1980 \mathrm{~s}$ & $2090 \mathrm{~s}$ & $10^{6} \mathrm{Mg} /$ year & $\%$ \\
\hline Africa & 2,966 & 4.4 & 6.0 & $+4,746$ & +36.3 \\
\hline Asia & 4,254 & 12.2 & 14.4 & $+9,359$ & +18.0 \\
\hline Australia/New Zealand & 882 & 3.0 & 4.1 & +970 & +36.7 \\
\hline Europe & 951 & 11.1 & 8.9 & $-2,092$ & -20.0 \\
\hline $\begin{array}{l}\text { North America and } \\
\text { Central America }\end{array}$ & 2,191 & 9.3 & 10.0 & $+1,533$ & +7.5 \\
\hline South America & 1,769 & 8.5 & 10.3 & $+3,184$ & +3.7 \\
\hline World & 13,013 & 10.2 & 11.6 & $+18,218$ & +13.7 \\
\hline
\end{tabular}


in soil quality and functions, (iii) widening gap between demand and supply of water, (iv) increase in environmental injustice arising from inequitable distribution of impacts and resources across social, gender, ethnic, cultural, and income divides, and (v) increase in civil conflict and political unrest. The increasing tide of environmental refugees from desertified land [59] prone to civil conflict [31] may also aggravate the adverse impact of the income divides. Decrease in per capita availability of fresh water resources may aggravate the civil conflict [38], and further increase soil degradation because of societal collapse [15]. Over and above the human dimensions, risks of erosion and desertification are also aggravated by uncontrolled fire and overgrazing [1,94].

\section{Drought and Desertification}

Rather than the total endowment of the global renewable water resources, important factors affecting drought and desertification are the hydrologic fluxes and their spatial and temporal variability [63]. Water resources are already scarce in arid/dry lands [3,27], and in the Arab countries [88]. Increasing water scarcity caused by ever growing population and its demands [87] may be accentuated further by global warming. Drylands (with $42 \%$ of the world population and $41 \%$ of the land area) are already the most vulnerable regions with regards to risks of desertification and drought. Yet, these regions are also likely to be even more adversely affected by the projected climate change, along with potential changes in agriculture and forestry in the arid and semi-arid tropics [91]. Life in some of these regions is already on the edge [16] because of widespread poverty, inequitable land distribution, environmental degradation, over exploitation of natural resources, and dependence on rainfed agriculture managed by extractive farming practices. There is a close link between climate change and water resources [74]. Thus, the projected climate change may affect all four types of drought (Fig. 4). These are [56]: (i) meteorological drought caused by a long-term decline in rainfall/precipitation [93], (ii) hydrological drought caused by prolonged periods of decline in surface run-off, fall in the ground water, and depletion of the aquifer, (iii) edaphic/pedologic drought caused by reduction in soil's available water capacity [18], and (iv) agricultural/ecological drought caused by low availability of soil water at critical stages of crop growth [102, 103]. Some climate models suggest that future global warming may reduce soil moisture storage over large areas in semiarid regions [55, 90]. Doubling of atmospheric $\mathrm{CO}_{2}$ may increase the area of desert land by $17 \%$ [20]. For example, the meteorological drought would be enhanced because of the decline in total and effective precipitation along with increase in temperature and evaporation. Hydrological drought would be increased because of the increase in frequency of extreme events and of the flood-drought syndrome also leading to drop in the water table and reduction in recharge of the aquifer. Evaporative increase could result in much reduced outflow. Edaphic/pedologic drought would be increased by accelerated soil erosion,

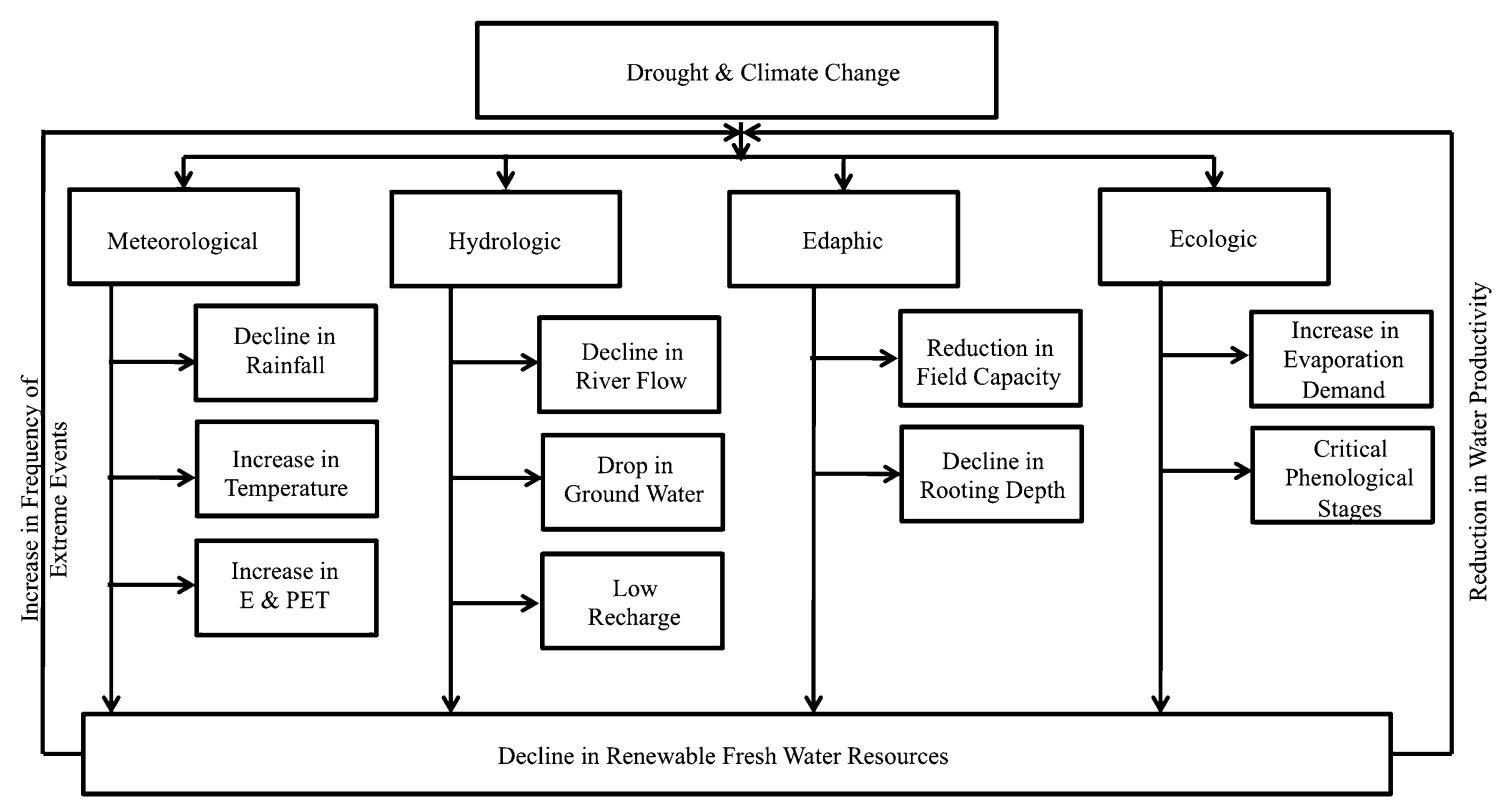

Fig. 4 Increase in intensity duration and frequency of drought because of long-term change in climate 
Fig. 5 Interaction between climate change and anthropogenic factors (i.e., over exploitation of the resource leading to societal collapse) exacerbating erosion and desertification

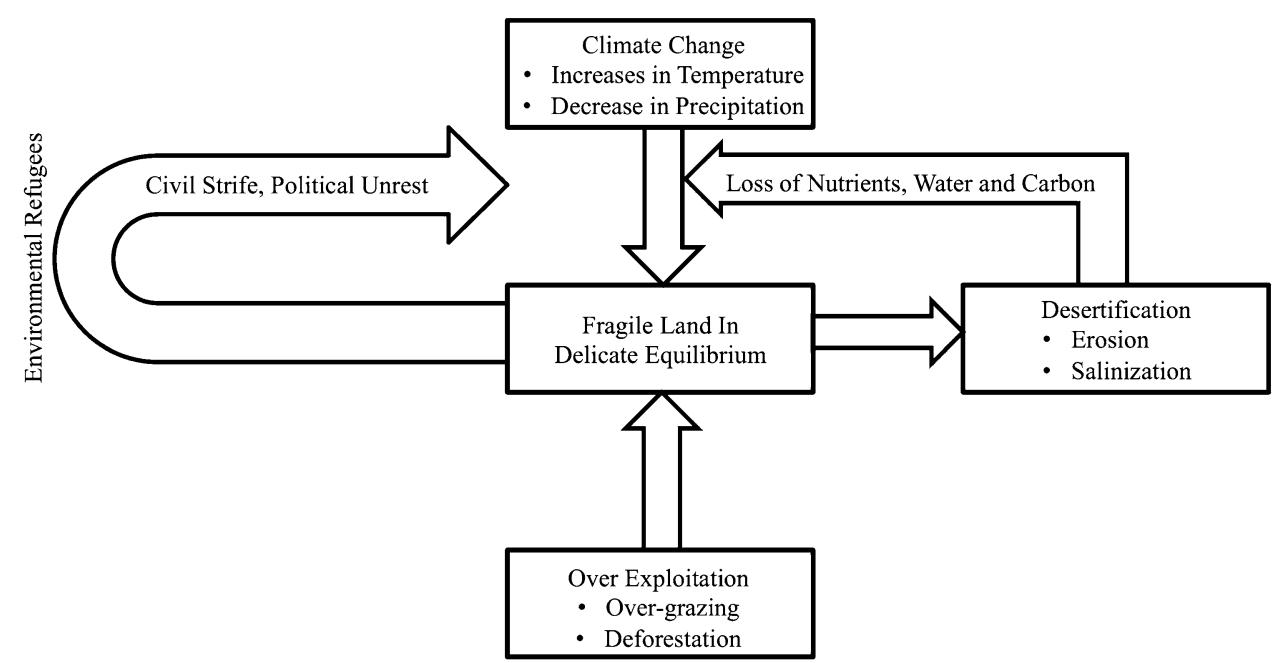

truncation of the surface soil, preferential removal of clay and SOC contents, decline in soil structure, and an overall reduction in plant-AWC. Feddema [24, 25] opined that climate change would reduce soil water holding capacity because of degradation in most watersheds of Africa. Thus, the ecological/agronomic drought would be enhanced because soils prone to desertification could become even less fertile and adversely affect crop growth during critical phonological stages. Reduction in summer soil wetness can occur by increase in atmospheric $\mathrm{CO}_{2}$ concentration [55]. Drought and soil/land degradation are closely inter-linked, and both are aggravated by the projected climate change, and are exacerbated by positive feedback related to the human dimensions (Fig. 5).

Ragab and Prudhomme [72] reported that by the 2050s, the West Asia North Africa (WANA) region may have 20-25\% less rainfall during the dry season than the present mean values. With the projected rise in temperature of between 2 and $2.75^{\circ} \mathrm{C}$, the aridization may enhance the risks of drought [88] and accelerated erosion by wind during the dry season. During the winter time, the rainfall for the same region may decrease by $10-15 \%$ in the south and by $5-10 \%$ in the north, with an average annual decrease of $\sim 10 \%$ [72]. In the Thar desert (India, Pakistan, Afghanistan), average increase in temperature ranges from 1.75 to $2.5{ }^{\circ} \mathrm{C}$ and decrease in rainfall by $5-25 \%$, with relatively more decrease in rainfall during the summer $(25 \%)$ than in the winter. Similar trends of increase in temperature have been projected for the Aral Sea basin in Central Asia, and for Australia. Whereas the rainfall may increase in Central Asia (10-25\%), it will decrease in Australia by 20-25\% in the south and 5-10\% in the north. Similar to the WANA regions, risks of drought and desertification will also increase in semi-arid and arid regions of Australia and South and Central Asia. The adverse effects, mostly in the tropics may include the following [36]: (i) decrease in the growing season duration, and (ii) increase in incidence of drought because of uncertainties of the monsoon. The agronomic drought may also be accentuated because of decrease in soil water storage caused by high losses (due to evaporation and run-off), reduction in SOC concentration and structural aggregation. The climate-induced intensification of the hydrologic cycle [33] lead to acceleration in evaporation, evapotranspiration, and run-off, and intensity of drought. Recent projected temperature increases in the twenty-first century are within the ranges of tipping points or critical thresholds with severe environmental consequences [54, 73]. The effects of tropical deforestation on reduction in precipitation and increase in temperature in the region (Amazon) have been widely established [53, 89]. Additional studies show that the deforestation of Amazon (also Sumatra, Central and West Africa) may significantly affect precipitation elsewhere especially at mid and high latitudes. Avissar and Werth [5] indicated interesting correlations between the hydrometeorology and the deforested regions and that of remote areas: (i) deforestation of Amazon and Central Africa severely reducing precipitation in lower U.S. Midwest during the spring and summer seasons and in upper U.S. Midwest during the winter and spring when water is crucial for crop growth, (ii) deforestation of Southeast Asia affecting precipitation in China and Balkan Peninsula. The combined effect of deforestation globally decreases winter precipitation in California [5].

Such coupling of hydrological and climatological factors, especially those which exacerbate risks of drought and desertification, necessitate prudential management of precipitation especially in dryland ecosystems [67]. The strategy is to build resilience to drought in desertification prone regions of Sub-Saharan Africa, WANA, Asia, North America, and South America [22]. 


\section{Mutually Reinforcing Positive Feedback Between Soil Degradation/Desertification and Climate Change}

A prudent management of the anthropocene through an earnest attempt by man to domesticate himself can reverse the downward spiral involving mutual reinforcing and positive feed backs. The severity of the problem is increased many fold because soil degradation would increase risks of climate change and vice versa in an accelerating spiral (Fig. 6).

The driving force in the environmental depletion and climate change issue is the human induced perturbation of the delicate balance in ecologically sensitive eco-regions (Fig. 7). There is a strong link between poverty, desperateness, societal collapse, and degradation. Reversing the downward spiral requires credible data, because there is no substitute for knowledge (Edward Deming, 1900-1993). Climate change may exacerbate desertification through alteration of several elements such as insolation, temperature, rainfall, and extreme events. Increase in temperature and evapotranspiration would adversely affect and denude the vegetation cover. Long-term drought can also alter the surface energy budget [61] especially through changes in albedo, soil moisture and other properties (i.e., compaction, crusting), surface roughness, atmospheric aerosol, atmospheric moisture [102]. Breaking the mutually enhancing positive feedback requires a strong knowledge of interannual and spatial variability in dryland precipitation, stream flow, soil moisture regime, and other parameters which affect the type and degree of drought. In this regards variations in the dryland soil moisture regime and the factors affecting it are of critical importance. There is a strong need for routine monitoring and modeling of soil moisture regime in relation to edaphic and ecological factors.

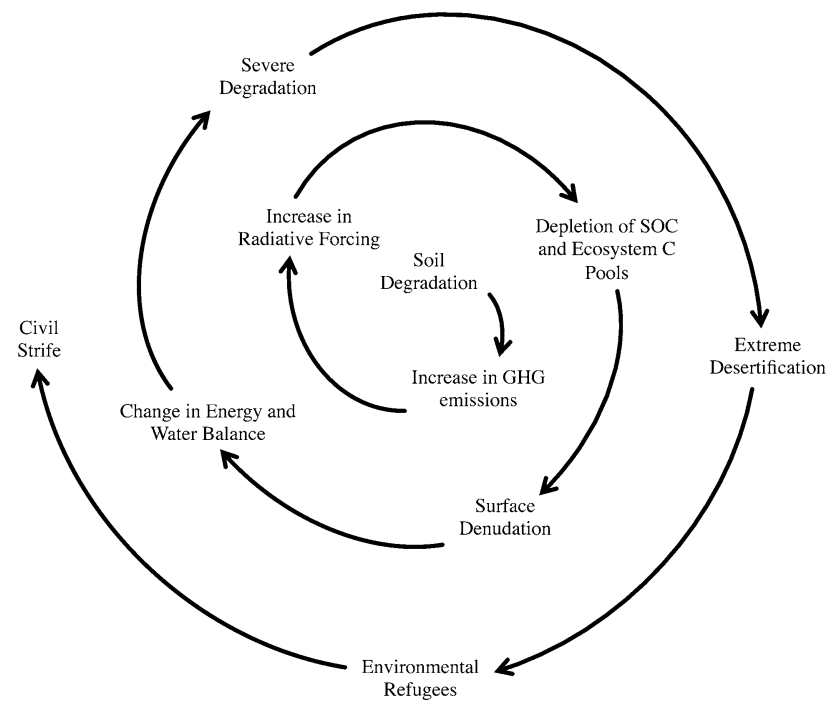

Fig. 6 The accelerating spiral of soil degradation and climate change interaction

\section{Drought, Degradation, and Carbon Sequestration}

Restoration of degraded soils by increasing length of the fallow period, converting marginal agricultural areas to rangeland, and conversion to a restorative land use have a

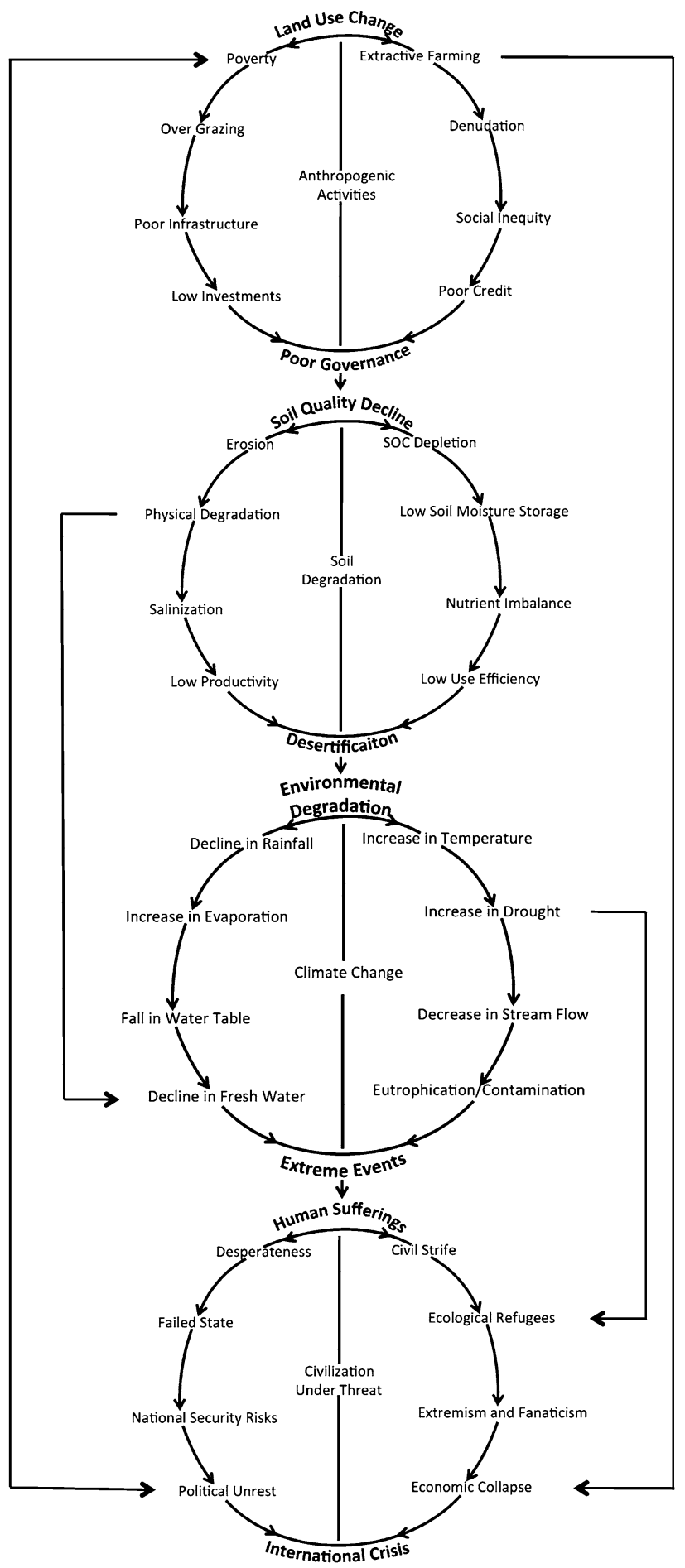

Fig. 7 Mutually reinforcing positive feedbacks between anthropogenic activities leading to soil degradation, desertification, and climate change 
large technical potential to sequester $\mathrm{C}$ in soils of degraded ecosystems [41, 42, 64] albeit at decadal scale [57]. Therefore, it has been optimistically proposed that irrigated afforestation of the Sahara and the Australian outback can end global warming [66]. Such a bold initiative would imply that man can indeed domesticate himself [76]. A fraction of the large technical potential can be realized only if adequate amount of water and nutrients are also available.

Similar to the potential benefits of the $\mathrm{CO}_{2}$ fertilization effect, those from off-setting of anthropogenic emission by $\mathrm{C}$ sequestration in soil and the terrestrial biosphere also cannot be harnessed when water is not adequately available. Jackson et al. [35] reported that establishment of tree plantations would decrease stream flow by $227 \mathrm{~mm}$ per year globally, with $13 \%$ of streams drying completely for at least 1 year. Nonetheless, plantation could improve ground water recharge and upwelling but reduce stream flow. It is because of nutrient and water related constraints that some argue regarding the limited potential for terrestrial C sequestration [26, 86], with perils and potential of this strategy [65]. However, there are numerous co-benefits of soil restoration, $\mathrm{C}$ sequestration and of strengthening the ecosystem resilience.

\section{Technological Options for Sustainable Management}

Protection of soils and natural resources is critical to maintaining ecosystem services (ESs) essential for human well-being and other functions [10]. Successful adaptation to climate change implies strong understanding of processes and properties of soils and the related natural resources, but also the response of the community. Engaging the natural resource management community [9] is important to promoting adoption of recommended management practices (RMPs), strengthening science/ public dialogue, and enhancing the awareness. Despite availability of a large amount of scientific data toward sustainable management of soils and natural resources since $1950 \mathrm{~s}$, about 1.4 billion resource-poor farmers located in risk-prone regions remain untouched by modern agricultural innovations. It is surmised by some that application of the principles of agroecology can provide the needed scientific basis to development and adoption of new management systems fine-tuned to highly variable and diverse farming conditions.

The strategy is to replace what is removed; wisely restore what is altered, and predict and manage what can happen to soil (and natural) resources by anthropogenic and natural perturbations. The ecosystem and soil $\mathrm{C}$ pools are critical attributes which affect soil quality and soil/ecosystem resilience. Thus, an important strategy is to enhance the soil and ecosystem $\mathrm{C}$ pool by strengthening recycling mechanisms, minimizing losses, and creating positive $\mathrm{C}$ and nutrient (N, P, K, S, and Zn) budgets. A brief analyses of the RMPs for sustainable development of agriculture and of natural resources are briefly discussed here.

\section{Soil Carbon and Nutrient Management}

Major RMPs include those involving soil and water conservation, conversion from plow till to no-till (NT) farming in conjunction with crop residue mulch and complex crop rotations grown with integrated nutrient management (INM), and use of biomass-C (i.e., manure, compost, mulch, and cover crop) needed to create a positive $\mathrm{C}$ budget [41-44] While the benefits of NT farming are widely known for upland production systems, the techniques is also being recommended and fine-tuned for ricebased systems [45]. The rice-wheat system, practiced on some 14 Mha of cropland in South Asia, provides the staple food grains to $8 \%$ of the world population. In South Asia, (Pakistan, India, Nepal, Bangladesh, Bhutan), the decline or stagnation of the productivity of rice-wheat system since 1990 s may be attributed to soil degradation, severe depletion of the SOC reserves, and nutrient imbalance/depletion. Therefore, conversion to mulch farming and NT for wheat, along with direct seeding of aerobic rice in an unpuddled soil in conjunction with a judicious combination of INM strategies and adequate weed control, can reverse the degradation trend, improve soil quality and enhance, and sustain agronomic productivity [45, 50]. Furthermore, present farm yields are low and hardly $40-60 \%$ of the attainable yield potential [17] and even lower $(20 \%)$ in degraded soils and marginal ecosystems. Such a large yield gap can be narrowed by adoption of INM strategies, which are also useful to enhance the SOC pool of degraded and depleted soils [41-44]. There is a widespread problem of nutrient imbalance, caused by an excessive use of highly subsidized $\mathrm{N}$ but not of expensive $\mathrm{P}$, and deficiency of micronutrients ( $\mathrm{Zn}, \mathrm{Fe}$, etc.). A judicious combination of inorganic fertilizers and organic amendments (compost, manure, and sludge) can alleviate this problem.

Similar to eroded and physically degraded soils, there is a large soil/ecosystem C sink capacity of chemically degraded soils. Important among these are salinized soils in arid and semi-arid ecosystems. In addition to enhancing agronomic productivity, reclamation of salt affected soils also has a high soil $\mathrm{C}$ sink capacity to off-set anthropogenic emissions [44].

\section{Water Management}

There is a close link between $\mathrm{C}, \mathrm{N}(\mathrm{P}, \mathrm{S})$, and water, and understanding and managing this link is important to 
improving soil quality and resilience. Water deficit, already a serious problem even in humid regions because of poor distribution, is likely to be exacerbated by the changing and uncertain climate with increase in frequency of extreme events. The drastic situations of water deficit in harsh environments of Middle Eastern regions [2] have led to some drastic measures such as changing texture of sandy soils by mixing clay to enhance water retention [4]. Sustainable waste water management, especially for small communities, in Middle East and elsewhere in arid and semi-arid regions, can be useful to improve agronomic production [7].

Another strategy is to explore the nexus between integrated natural resource management (NRM) and integrated water resource management [95] because of the co-cycling within an ecosystem/watershed. The strategy is to redirect blue water issues to green water issues and vice versa [22, 23]. Indeed, sound water management requires a better understanding of the opportunity cost of water and greater coordination of sectoral strategies, especially among agriculture, industry, and urban uses [48].

In the final analyses, the significance of the judicious NRM within a watershed (especially in semi-arid and arid regions) cannot be over emphasized. Indeed, the integrated use of soil and water conservation practices with balanced plant nutrition is an important basis of enhancing the water productivity and resource use efficiency [82]. The goal is to effectively manage the precipitation [67] to obtain more crops per drop of water.

Then, there is also an important issue of wetland and their management, because wetland ecosystems are a natural resource of global significance [100]. Wetlands, as kidneys of the ecosystem, provide protection against floods and non-point sources pollution, and are also a major source of fresh water. Wetlands have numerous ESs (e.g., biodiversity, C sequestration, water purification and decontamination, aquaculture, and wetland restoration) and can enhance these ESs, especially the C sink capacity to off-set anthropogenic emissions [47]. In this regards, it is important to realize that wetlands are prone to drainage and degradation especially in arid regions. Eutrophication is a major threat to hydrophytic and other hydric species [14], and policy interventions are needed to protect and restore these valuable resources.

\section{Forest Management}

A judicious management of the humid tropical forests (spanning $\sim 5^{\circ} \mathrm{N}$ and $\mathrm{S}$ of the equator) is important to numerous ESs of global significance. Given the significance to global $\mathrm{C}$ and water cycles and conservation of biodiversity, tropical forest resources must be protected and restored. Forest management, and integration of trees with crops and livestock through appropriate agroforestry systems, can also conserve and improve soil and ecosystem C pools. Phat et al. [68] reported that between 1990 and 2000 in Southeast Asia, about 2.3 Mha of forest were cleared every year and emitted $46.5 \mathrm{Tg}$ of $\mathrm{C}$ into the atmosphere ( $\sim 29 \%$ of the global net $\mathrm{C}$ release by deforestation). Thus, there is a strong need to develop policy for reforestation and afforestation of the previously deforested land. Scatena [85] advocated the use of ecological rhythms in the management of endangered species and water resources in the Caribbean. Such a dynamic management is a challenging task. However, integrating ecological rhythms into management options is an important strategy for both tropical and temperate environments. Similarly, a judicious management of plantation forests is an opportunity and a challenge. Implications for biodiversity of the intensively managed plantations are a major issue. Although natural forests are a better habitat for biodiversity, judicious management of plantation forests can provide a valuable habitat [11], while also creating other ESs. During the early stages of tree development, agroforestry techniques can be adapted to enhance productivity and biodiversity [58].

Similar to the rainforest biome, tropical grasslands and savannas occupy approximately 210 Mha in South America [99]. Reconciling intensified grazing systems with NT farming and INM have a large soil/ecosystem C sink capacity [46].

\section{New Research and Analytical Tools}

Strong scientific understanding is the basis for identifying technological options to be implemented for sustainable NRM. The knowledge base improvement requires credible data from long-term hypothesis based research to establish the cause-effect relationship [30]. In addition, innovative experimental techniques can improve the data procurement, analyses and synthesis. Remote sensing and the geographic information system (GIS) are useful tools to assess ecosystem characteristics and functions [37]. These techniques can be used to study the change in land-use/cover and soil degradation in diverse ecoregions. There are also several modeling techniques to study biophysical processes, and also assess the anthropogenic interactions or the human dimensions of ecosystems. Nautiyal and Kaechele [60] used modeling approach to understanding how human behavior is changing under shifting political, socioeconomic, and environmental conditions in the Indian Himalayas. There are also decision support system (DSS) for soils and water conservation within a watershed. Saragni et al. [84] used DSS for generating alternative decision support scenarios to facilitate integrated watershed management concepts in an interactive and holistic manner. 
Sustainable management must also be linked to sustainable governance of natural resources. Sustainable governance is essential to place the politically neutralizing discourse of management in the context of a wider social debate to discuss and negotiate the norms, rules, etc., of NRM and sustainable development [78]. Thus, there is a need for the judicious governance of natural resources. The goal is to move from strategic action to communicative action [78].

There is a philosophical emphasis on the strategy of community-based natural resource management (CBNRM). The latter involves the governance of economic processes, property right, and local political organizations [12]. It implies replacement of fiscal centralization, fees and bureaucracy which have undervalued natural resources to provide comparative economic advantage to small land holders with community incentives. The resource governance should be shifted to the community, thus benefits can be shared at the local level. To be successful, CBNRM strategy must be accountable, transparent, and based on equitable governance at micro- and meso-level [12].

An important among NRM techniques is the assessment of the environmental impacts of developmental/land use/ cover options. The strategy is to assess the ecological footprint by conducting life cycle analyses (LCA). The environmental protection and conservation being critical to maintaining ESs, it is important to rank countries or communities by their environmental impact. During the early 1970s Commoner and others [13, 19] developed a conceptual equation:

$I=P A T$

where, $I$ is the environmental impact, $P$ is population, $A$ is affluence, and $T$ is technology. This equation has been used to emphasize the contribution of a growing global population on the environment. This and other equations can be used to rank countries by their environmental impact so that poor performers and policy models can be identified [10]. This ranking is important to punish the polluters and reward the stewards.

\section{Conclusions}

There exists a close link between soil erosion/degradation, climate change, and poverty. Soil degradation creates a positive feedback attributed to emission of radiatively active gases depletion of soil organic carbon and nutrient pools, denudation of vegetation cover, and reduction in net primary productivity, increase in frequency and intensity of droughts (especially pedological and ecological droughts), and loss of ecosystem resilience. There is a strong need for prudent management of soil, vegetation, water, and other natural resources. Restoration of degraded soils can increase the ecosystem $\mathrm{C}$ pool provided that available water and plant nutrients are adequate. Establishment of tree plantations can reduce stream flow while also decreasing albedo. The strong link between the climatevegetation-soil-water-continuum and anthropogenic activities necessitate a prudent and a coordinated effort to reverse the downward spiral, restore degraded soils, mitigate climate change, and enhance ecosystem services. There are new tools and techniques available to measure, monitor and verify the status of soils, and natural resources. The community-based natural resources management is a useful strategy for judicious governance. The strategy is to shift from strategic action to strategic governance.

\section{References}

1. Abril A, Barttfeld P, Bucher EH (2005) The effect of fire and overgrazing disturbed on soil carbon balance in the Dry Chaco forest. For Ecol Manage 206:399-405

2. Abu Zahra BAA (2001) Water crisis in Palestine. Desalination 136(1-2):93-99

3. Agnew C, Anderson E (1992) Water resources in the arid realm. Routledge, London

4. Al-Omran AM, Falatah AM, Sheta AS, Al-Harbi AR (2004) Clay deposits for water management in sandy soils. Arid Land Res Manag 18(2):171-183

5. Avissar R, Werth D (2005) Global hydroclimatological teleconnections resulting from tropical deforestation. J Hydrometeorol 6:135-145

6. Bai ZG, Dent DL, Olsson L, Schaepman ME (2008) Proxy global assessment of land degradation. Soil Use Manag 24:223-234

7. Bakir HA (2001) Sustainable wastewater management for small communities in the Middle East and North Africa. J Environ Manag 61(4):319-328

8. Balling RC Jr (1991) Impact of desertification on regional and global warming. Bull Am Meteorol Soc 72:232-234

9. Bardsley DK, Rogers GP (2011) Prioritizing engagement for sustainable adaption to climate change: and example from natural resource management in South Africa. Soc Nat Resour 24:1-17

10. Bradshaw CJA, Giam X, Sodhi NS (2010) Evaluating the relative environmental impact of countries. PlosOne 5(5):1-16

11. Brockerhoff EG, Jacktel H, Parrotta JA, Quine CP, Sayer J (2008) Plantation forests and biodiversity: oxymoron or opportunity? Biodivers Conserv 17(5):925-951

12. Child B, Barnes G (2010) The conceptual evolution and practice of community-based natural resource management in southern Africa: past, present and future. Environ Conserv 37:283-295

13. Commoner B (1972) The environmental cost of economic growth. In: Population resources and the environment. Govt. Printing Office, Washington, DC, pp 339-363

14. Daoud-Bouattour A, Muller SD, Jamaa HF, Saad-Limam SB, Rhazi L, Soullé-Märsche I, Rouissi M, Touati B, Jillani IB, Gammar AM, Ghrabi-Gammar Z (2011) Conservation of Mediterranean wetlands: interest of historical approach. CR Biol 334(10):742-756

15. Diamond J (2005) Collapse: how societies choose to fail or succeed?. Penguin, New York 
16. Dixon RK, Smith J, Guill S (2003) Life on the edge: vulnerability and adaptation of African ecosystems to global climate change. Mitig Adapt Strategies Glob Change 8:93-113

17. Dobermann A, Cassman KG (2002) Plant nutrient management for enhanced productivity in intensive grain production systems of the United States and Asia. Plant Soil 247:153-175

18. Dracup JA, Lee KS, Paulson EG (1980) On the definition of droughts. Wat Resour Res 16:297-302

19. Ehrlich PR, Holdren JP (1971) Impact of population growth. Science 171:1212-1217

20. Emanuel KA (1987) The dependence of hurricane intensity on climate. Nature 326:483-485

21. Eswaran H, Reich P, Beinroth F (2001) Global desertification tension zones. In: Stott DE, Mohtar RH, Steinhardt GC (eds) Sustaining the global farm. Selected papers from the 10th international soil conservation organization meeting held May 24-29, 1999 at Purdue University and the USDA-ARS National Soil Erosion Research Laboratory, West Lafayette

22. Falkenmark M, Rockström J (2008) Building resilience to drought in desertification-prone savannas in Sub-Saharan Africa: the water perspective. Nat Resour Forum 32:93-102

23. Falkenmark M, Rockström J (2004) Balancing water for human and nature: the new approach to ecohydrology. Earthscan, London

24. Feddema JJ (1998) Estimated impacts of soil degradation on the African water balance and climate. Clim Res 10:127-141

25. Feddema JJ (1999) Future African water resources: interactions between soil degradation and global warming. Clim Change 42:561-596

26. Fissore C, Espeleta J, Nater EA, Hobbie SE, Reich PB (2010) Limited potential for terrestrial carbon sequestration to offset fossil-fuel emissions in the upper Midwestern US. Front Ecol Environ 8(8):409-413

27. Gischler CE (1979) Water resources in the Arab Middle East and North Africa. MENA resources studies-Middle East \& North African studies. Press Ltd. Wisbeach

28. Haddad N, Duwayri M, Oweis T, Bishaw Z, Rischkowsky B, Hassan AA, Grendo S (2011) The potential of small-scale rainfed agriculture to strengthen food security in Arab countries. Food Secur 3:163-173

29. Harte J (2007) Human population as a dynamic factor in environmental degradation. Popul Environ 28:223-236

30. Havens KE, Aumen NG (2000) Hypothesis-driven experimental research is necessary for natural resource management. Environ Manag 25(1):1-7

31. Hendrix CS, Glaser SM (2007) Trends and triggers: climate, climate change and civil conflict in Sub-Saharan Africa. Political Geogr 26:695-715

32. Hulme M, Kelly M (1993) Exploring the links between desertification and climate change. Environment 35(6):4-45

33. Huntington TG (2010) Climate warming-induced intensification of the hydrologic cycle: an assessment of the published record and potential impacts on agriculture. Adv Agron 109:1-53

34. IPCC (2007) Climate change. The physical science basis. Cambridge University Press, Cambridge

35. Jackson RB, Jobbágy EG, Avissar R, Roy BS, Barrett D, Cook CW, Farley KA, Le Maitne BA (2005) Trading water for carbon with biological carbon sequestration. Science 310:1944-1947

36. Jager J, Ferguson HL (1991) Climate change: science, impacts and policy. In: Proceedings of the second world climate conference. Cambridge University Press, Cambridge

37. Junge B, Alabi T, Sonder K, Marcus S, Abaidoo R, Chkoye D, Stahr K (2010) Use of remote sensing and GIS for improved natural resources management: case study from different agroecological zones of West Africa. Int J Remote Sens 31: 6115-6141
38. Kilot N (1994) Water resources and conflict in the Middle East. Routledge, London

39. Lal R (1999) Soil management and restoration for carbon sequestration to mitigate the greenhouse effect. Prog Env Sci $1: 307-326$

40. Lal R (2001) Soil degradation by erosion. Land Degrad Dev 12:519-539

41. Lal R (2004) A carbon sequestration in dryland ecosystems of West Asia and North Africa. Land Degrad Develop 13:45-49

42. Lal R (2004) Soil carbon sequestration impacts on global climate change and food security. Science 304:1623-1627

43. Lal R (2010) Managing soils and ecosystems for mitigating anthropogenic carbon emissions and advancing global food security. Bioscience 60:708-721

44. Lal R (2010) Carbon sequestration in saline soils. J Soil Salin Water Qual 1:30-40

45. Lal R, Hobbs P, Uphoff N, Hansen DO (2004) In: Lal R, Hobbs P, Uphoff N, Hansen DO (eds) Sustainable agriculture and the international rice-wheat system. Marcel Dekker, New York, p 532

46. Lal R, Cerri C, Bernoux M, Echevers J (2006) In: Lal R, Cerri C, Bernoux M, Echevers J (eds) The potential of soils of Latin America to sequester carbon and mitigate climate change. The Haworth Press, West Hazelton

47. Lal R, Lorenz K, Hüttl, Schneifer BU, von Braun J (eds) (2012) Recarbonization of the biosphere. Springer, Dordrecht

48. Lange GM (1998) An approach to sustainable water management in Southern Africa using natural resource accounts: the experience in Namibia. Ecol Eco 26:299-311

49. Lavee H, Imeson AC, Sarah P (1998) The impacts of climate change on geomorphology and desertification along a Mediterranean-arid transect. Land Degrad Develop 9:407-422

50. Laxmi V, Erenstein O, Gupta RK (2007) CIMMYT. Assessing the impact of natural resource management research: the case of zero tillage in India's rice-wheat systems. In: Waibel $\mathrm{H}$, Zilberman D (eds) International research in natural resource management: advances in impact assessment. CABI, Wallingford. doi: $10.1079 / 9781845932831.0000$

51. Le Houerou HN (2002) Man-made deserts: desertization processes and threats. Arid Land Res Manag 16(1):1-36

52. Le Houérou HN (1996) Climate change, drought and desertification. J Arid Environ 34:133-185

53. Lean J, Warrilow DA (1989) Simulation of the regional climatic impact of Amazon deforestation. Nature 342:411-413

54. Lenton TM, Held H, Kriegler E, Hall JW, Lucht W, Rahmstorf S, Schellnhuber HJ (2008) Tipping elements in the earth's climate system. Proc Natl Acad Sci 105:1786-1793

55. Manabe S, Wetherland RT (1986) Reduction in summer soil wetness induced by increase in atmospheric carbon dioxide. Science 232:626-628

56. Maybank J, Bonsal B, Jones K, Lawford RG, O’Brien EG, Ripley EA, Wheaton E (1995) Drought as a natural disaster. Atmos-Ocean 33:195-222

57. McLauchlan KK, Hobbie SE, Post WM (2006) Conversion from agriculture to grassland builds soil organic matter on decadal timescales. Eco Appl 16:143-153

58. McNeely JA, Schroth G (2006) Agroforestry and biodiversity conservation - traditional practices, present dynamics, and lessons for the future. Biodivers Conserv 15(2):549-554

59. Myers N (2002) Environmental refugees: a growing phenomenon of the 21st century. Phil Trans R Soc Lond B 357:609-613

60. Nautiyal S, Kaechele H (2009) Natural research management in a protected area of the Indian Himalayas: a modeling approach for anthropogenic interactions on ecosystem. Environ Monit Assess 153:253-271 
61. Nicholson SE (1988) Land surface-atmosphere interaction: physical processes and surface changes and their impact. Prog Phys Geor 12:36-65

62. Oba G, Post E, Stenseth NC (2001) Sub-Saharan desertification and productivity are linked to hemispheric climate variability. Glob Change Biol 7:241-246

63. Oki T, Kanae S (2006) Global hydrological cycles and world water resources. Science 313:1068-1072

64. Oldeman LR (1994) The global extent of soil degradation. In: Greenland DJ, Szabolcs I (eds) Soil resilience and sustainable land use. CAB International, Wallingford, UK, pp 99-118

65. Olsson L, Ardö J (2002) Soil carbon sequestration in degraded semiarid agro-ecosystem-perils and potentials. Ambio 31(6): 471-477

66. Ornstein L, Aleinov I, Rind D (2009) Irrigated afforestation of the Sahara and Australian outback to end global warming. Clim Change. 97:409-437. doi:10.1007/s10584-009-9626-y

67. Peterson GA, Westfall DG (2004) Managing precipitation use in sustainable dryland agroecosystems. Ann Appl Biol 144:127-138

68. Phat NK, Knorr W, Sophanarith K (2004) Appropriate measures for conservation of terrestrial carbon stocks-analysis of trends of forest management in Southeast Asia. Frest Ecol Manag 191:283-299

69. Puigdefábregas J (1998) Ecological impacts of global change on drylands and their implications for desertification. Land Degrad Dev 9:393-406

70. Puigdefábregas J, Sánchez G (1996) Geomorphological implications of vegetation patchiness in semi-arid slopes. In: Anderson M, Brooks S (eds) Advances in Hillslope processes, vol 2. Wiley, Chichester

71. Puigdefábregas J, Aguilera C, Brenner A, Alonso JM, Delgado L, Domingo F, Cueto M, Gutierrez L, Lazaro R, Nicolau JM, Sanchez G, Sole A, Vidal S, Clark S, Incoll L (1996) The Rambla Honda field site. Interactions of soil and vegetation along a catena in a semi-arid SE Spain. In: Thornes J, Brandt J (eds) Mediterranean desertification and land use. Wiley, Chichester

72. Ragab R, Prudhomme C (2002) Climate change and water resources management in arid and semi-arid regions: prospective and challenges for the 21st century. Biosyst Eng 81:3-34

73. Ramanathan V, Feng Y (2008) On avoiding dangerous anthropogenic interference with the climate system: formidable challenges ahead. Proc Natl Acad Sci 105:14245-14250

74. Reibsame WE, Strzepek KM, Wescoat JL Jr, Perritt R, Gaile GL, Jacobs J, Leichenko R, Magadza C, Phiem H, Urbiztondo BJ, Restrepo P, Rose WR, Saleh M, Ti LH, Tucci C, Yates D (1995) Complex river basins. In: Strzepek KM, Smith JB (eds) As climate changes. Cambridge University Press, Cambridge

75. Rengasamy P (2006) World salinization with emphasis on Australia. J Exp Bot 57(5):1017-1023

76. Revelle R (1966) Can man domesticate himself? Bulletin of the Atomic Scientists. Harvard School of Public Health. Center for Population Studies

77. Reynolds JF, Stafford Smith DM, Lambin EF, Turner BL, Mortimor M, Batterbury SPJ, Downing TE, Dowlatabad H, Fernandez RJ, Herrick JE, Huber-Sannwald E, Jiang H, Leemans R, Lynam T, Maestne FT, Ayarza M, Walker B (2007) Global desertification: building a science for drylands development. Science 316(5826):847-851

78. Rist S, Chidambaranathan M, Escobar C, Wiesmann U, Zimmermann A (2007) Moving from sustainable management to sustainable governance of natural resources: the role of social learning processes in rural India, Bolivia and Mali. J Rural Stud 23:23-37

79. Ruddiman WF (2003) The anthropogenic greenhouse era began thousands of years ago. Clim Change 61:261-293
80. Ruddiman WF (2007) The early anthropogenic hypothesis: challenges and responses. Reviews of Geophysics 45(2006RG 000207R). doi:10.1029/2006RG000207

81. Ruddiman WF, Ellis EC (2009) Effect of per capita land use changes on Holocene forest clearance. Quat Sci Rev 28: 3011-3015

82. Sahrawat KL, Wani SP, Pathak P, Rego TJ (2010) Managing natural resources of watersheds in the semi-arid tropics for improved soil and water quality: a review. Agric Water Manag 97:375-381

83. Salinger JM (2005) Climate variability and change: past, present and future- an overview. Clim Change 70:9-29

84. Sarangi A, Madramootoo CA, Cox C (2004) A decision support system for soil and water conservation measures on agricultural watersheds. Land Degrad Dev 15(1):49-63

85. Scatena FN (2001) Ecological rhythms and the management of humid tropical forests - examples from the Caribbean National Forest Puerto Rico. Forest Ecol Manag 154(3):453-464

86. Schlesinger WH (1999) Carbon sequestration in soils. Science 284:2095

87. Seckler D, Amarasinghe U, Molden D, DE Silva R, Barker R (1998) World water demand and supply, 1990 to 2025: scenarios and issues. Research Report 19. International Water Management Institute, Colombo

88. Shahin M (1996) Hydrology and scarcity of water resources in the Arab region. IHE Monograph 1. A. A. Balkema/Rotterdam/ Brookfield

89. Shukla J, Nobre C, Sellers P (1990) Amazon deforestation and climate change. Science 247:1322-1325

90. Sivakumar MVK (2007) Interactions between climate and desertification. Agric For Meteorol 142:143-155

91. Sivakumar MVK, Das HP, Brunni O (2005) Impacts of present and future climate variability and change on agriculture and forestry in the arid and semi-arid tropics. Clim Change 70:31-72

92. Sterk G, Riksen M, Goossens D (2001) Dryland degradation by wind erosion and its control. Ann AridZone 40(3):351-367

93. Street RB, Findlay BF (1981) An objective climatological study of prolonged dry spells (meteorological drought) in the Canadian Prairies (pp 29) Report \#81-10, Canadian Climate Center, AES, Downsview

94. Thomas DSG, Sporton D, Perkins J (2000) The environmental impact of livestock ranches in the Kalahari, Botswana: natural resource of use, ecological change and human response in a dynamic dryland system. Land Degrad Dev 11:327-341

95. Twomlow S, Love D, Walker S (2008) The nexus between integrated natural resource management and integrated water resources management in southern Africa. Phys Chem Earth 33:8-13

96. UNEP (1991) World atlas of desertification. Edward Arnold, Sevenoaks

97. UNEP (United Nations Environment Program) (1977) Draft plan of action to combat desertification. Nairobi, Kenya

98. Veldman JW, Putz FE (2011) Grass dominated vegetation, not species-diverse natural savanna, replaces degraded tropical forests on the southern edge of the Amazon Basin. Bio Conserv 144(5):1419-1429

99. Vera RR, Hoyos P, Moya MC (1998) Pasture renovation practices of farmers in the neotropical savannas. Land Degrad Dev 9:47-56

100. Verhoeven JTA, Beltman B, Bobbink R, Whigham DF (2006) Wetland functioning in a changing world: implications for natural resource management. In: Verheven JTA, Beltman B, Bobbimk R, Whigham DF (eds) Ecological studies: analysis and synthesis. Ecol Stud 190:1-12 
101. West JM, Julius SH, Kareiva P, Enquist C, Lawler JJ, Petersen B, Johnson AE, Shaw MR (2009) US natural resources and climate change: concepts and approaches for management adoption. Environ Manag 44(6):1001-1021

102. Williams MAJ, Balling RC (1996) Interactions of desertification and climate. WMO, Geneva, p 230
103. WMO (1975) Drought in agriculture (Prepared by Hounam CE, Burgos JJ, Kalik MD, Palmer CW, Rodda J) Technical Note \#138, Geneva

104. Yang D, Kanae S, Oki T, Koike T, Musiake K (2003) Global potential soil erosion with reference to land use and climate changes. Hydrol Proc 17:2913-2928 